\title{
The Influence of Mitogen Costimulation on the Human Lymphocyte Blastogenic Response to Actinomyces viscosus Ultrasonicates
}

\author{
Dennis E. Lopatin, Frances L. Peebles, and Irene S. Horner \\ Dental Research Institute, and Departments of Oral Biology and \\ Microbiology-Immunology, University of Michigan, Ann Arbor. Michigan 48109
}

Received July 19. 1979

\begin{abstract}
Human peripheral blood lymphocytes were cultured for $48 \mathrm{hr}$ in the presence of an ultrasonicate supernatant fraction of Actinomyces viscosus (AV-SUP). After washing to remove AV-SUP, the lymphocytes were cultured in the presence of concanavalin $A$ or pokeweed mitogen for an additional $72 \mathrm{hr}$. Measurement of [ $\left.{ }^{3} \mathrm{H}\right]$ thymidine incorporation into DNA indicated that AV-SUP preculture resulted in an amplified or elevated response to mitogen stimulation compared to mock precultured cells and unstimulated controls. Addition of fresh cells prior to mitogen activation resulted in an additional incremental increase over controls. The modulated cell appeared to reside in the $\Lambda \mathrm{V}$ SUP precultured population, since treatment of these cells with mitomycin $\mathrm{C}$ prior to coculture with fresh cells totally abrogated the effect. However, mitomycin C treatment of the fresh population had no effect on mitogen-induced amplification. Results of these experiments suggest that mitogen stimulation activates a helper function which allows the precultured cells to respond to AV-SUP stimulation.
\end{abstract}

\section{INTRODUCTION}

Polyclonal B-cell activators have been obtained from a variety of microbial sources and have been extensively used to assess mechanisms of immunoglobulin synthesis $(1,2)$. Lipopolysaccharide (LPS), while a potent inducer of murine lymphocyte blastogenesis, has been reported to be unable to activate human lymphocytes obtained from peripheral blood $(3,4)$. Interpretations of these experiments suggested the lack of mitogen-reactive cells in the peripheral blood of humans. However, reports by Miller et al. (5) indicated that human lymphocytes can respond blastogenically to LPS. Such a response, however, required a much longer induction period ( $7-9$ days) than generally employed. They also reported the requirement of an accessory $\mathrm{T}$ cell in order to induce a maximum response. Response to other B-cell mitogens, such as pokeweed mitogen (PWM), has been shown to require an accessory $\mathrm{T}$ cell for polyclonal B-cell activation (6-9).

Recent reports have indicated that ultrasonicated preparations of Actinomyces viscosus also contained polyclonal B-cell activators for murine lymphocytes (10, 11). However, in human studies, a blastogenic response to such preparations was associated with a periodontal disease state (12) and was consistent with an antigenic, rather than mitogenic stimulation (13). Since studies by Schmidtke and Najarian (4) demonstrated that purified LPS could influence mitogen responsiveness in the absence of a direct response to LPS alone, we felt that the $A$. viscosus mitogen might also have a similar influence. Induction of a regulatory activity might be dissociated from the induction of blastogenic activity as shown in other 
cell models employing concanavalin A-stimulated regulatory cell activation initially described by Shou et al. (14). Characterization of that model showed that blastogenic activity could be dissociated from regulatory activity induction and was not a prerequisite for its induction (15). In this report, we describe the influence of mitogenic stimulation on the blastogenic response of human peripheral blood lymphocytes precultured with $A$. viscosis.

\section{MATERIALS AND METHODS}

\section{Lymphocyte Suspensions}

Mononuclear leukocytes were isolated from heparinized venous blood drawn from 25 healthy volunteers between the ages of 21 and 40 . Briefly, the buffy coat layer was prepared from whole blood by centrifugation at $350 \mathrm{~g}$ for $30 \mathrm{~min}$. The buffy coat was aspirated and diluted in sterile phosphate-buffered saline (PBS), pH 7.4, and layered onto Ficoll-Hypaque (16) (Ficoll-Paque, Pharmacia Fine Chemicals, Piscataway, N.J.) and centrifuged at $500 \mathrm{~g}$ for $30 \mathrm{~min}$ at $23^{\circ} \mathrm{C}$. The mononuclear leukocytes, which were banded at the interface, were aspirated. washed three times in PBS, resuspended in RPMI 1640 culture medium (Grand Island Biological Co., Grand Island, N.Y.), and supplemented with $40 \mathrm{~m} M$ Hepes buffer, $2 \mathrm{~m} M$ glutamine, and gentamicin $(50 \mu \mathrm{g} / \mathrm{ml}$ : Schering Corp., Kenilworth. N.J.).

\section{Actinomyces viscosus Ultrasonicate Preparations and Mitogens}

An isolate of $A$. viscosus strain GA, a catalase positive, filamentous rod. characterized according to criteria described by Holmberg and Hallender (17). was obtained from a naturally occurring gingivitis site, supplied by Dr. Salam A. Syed of the Dental Research Institute (University of Michigan). The cultures were grown under anaerobic conditions for 60-72 hr as previously described by Loesche $e t$ al. (18). The cells were harvested from broth cultures by centrifugation at $12,000 \mathrm{~g}$ for $30 \mathrm{~min}$. The cell pellets were washed extensively in sterile PBS and finally resuspended in sterile distilled water. Washed cells were subjected to a total of $40 \mathrm{~min}$ of ultrasonic disruption while in an ice bath (Heat Systems - UItrasonics, Inc., Model W185D, 84 W), and delivered in 5-min intervals with alternating periods of cooling. At the completion of cellular disruption, as determined by phase contrast microscopy and gram staining (greater than $95 \%$ of cells disrupted), the cellular debris was removed by centrifugation at $12,000 \mathrm{~g}$ for $30 \mathrm{~min}$. The cell-free supernatant was extensively dialyzed against distilled water at $4^{\circ} \mathrm{C}$ and finally lyophilized.

Concanavalin A (con A) was obtained from Pharmacia Fine Chemicals, and pokeweed mitogen (PWM) from Grand Island Biological Company.

Preculture with Actinomyces viscosus Supernate ( $A V$-SUP)

Lymphocyte suspensions $\left(5 \times 10^{6}\right.$ cells $/ \mathrm{ml}$ RPMI 1640) in sterile $12 \times 75-\mathrm{mm}$ polypropylene culture tubes with snap-on caps were cultured with AV-SUP $(1-1000 \mu \mathrm{g} / \mathrm{ml})$. Control cultures were prepared without added AV-SUP. Following incubation for $48 \mathrm{hr}$ at $37^{\circ} \mathrm{C}$ in $5 \% \mathrm{CO}_{2}$ in a humidified environment, the cells were washed with RPMI 1640 culture medium and resuspended to a final concentration of $1 \times 10^{6} \mathrm{cells} / \mathrm{ml}$. Viability of lymphocytes was assessed by trypan 
blue dye exclusion and was found to be in excess of $90 \%$ after $48 \mathrm{hr}$ of culture. Total cell recoveries were $60-80 \%$ for both control and AV-SUP preincubations.

In experiments elucidating the cells responsible for modulatory effects. mitomycin C $(50 \mu \mathrm{g} / \mathrm{ml}$ ) (Sigma Chemical Co., St. Louis, Mo.) was added to the lymphocyte suspensions following preincubation with AV-SUP to inhibit DNA synthetic activity. The cells were treated for $30 \mathrm{~min}$ at $37^{\circ} \mathrm{C}$ and exhaustively washed with RPMI 1640. Cells preincubated with AV-SUP or controls will be referred to as Stage I cells throughout this report.

\section{Mitogen Costimulation}

Fresh autologous lymphocytes were obtained following the 48-hr Stage I incubation period. Fifty thousand cells were added to flat-bottom microtiter plate wells containing either 50,000 AV-SUP preincubated or 50,000 control cells. Mitogens were then added to cultures (con A, 0.1 to $100 \mu \mathrm{g} / \mathrm{ml}$; PWM, $1 / 10$ to $1 / 1000$ ) in triplicate wells. Four major culture categories were prepared: (i) Control (no Stage I stimulants) preincubated cells plus fresh cells, (ii) control preincubated cells plus fresh cells and mitogen, (iii) AV-SUP preincubated cells plus fresh cells, and (iv) AV-SUP preincubated cells plus fresh cells and mitogen. In addition, all cultures contained a final concentration of $10 \%$ autologous plasma. These cell mixtures were incubated for 72 or $120 \mathrm{hr}$ at $37^{\circ} \mathrm{C}$. These cultures will be referred to as Stage II cultures throughout this report.

Six hours prior to termination of cell culture, $2 \mu \mathrm{Ci}$ of $\left[\right.$ methyl- $\left.{ }^{3} \mathrm{H}\right]$ thymidine (Amersham/Searle, Arlington Heights, Ill., TRA $120,5 \mathrm{Ci} / \mathrm{mmol}$ ) was added to each well. All cultures were harvested with a multiple-automated sample harvester (MASH II, Microbiological Associates, Bethesda, Md.) onto glass fiber filters. The filters were dried, placed in vials (Bio-Vial, Beckman Instruments, Fullerton, Calif.), filled with $3 \mathrm{ml}$ scintillation cocktail (OCS, Amersham/Searle), and counted in a Packard Model 3320 liquid scintillation spectrometer.

\section{RESULTS}

\section{Effect of AV-SUP Preculture and Subsequent Mitogen Stimulation}

Other investigators have shown that preculture of human peripheral blood lymphocytes (PBLs) with mitogens such as concanavalin A or phytohemagglutinin resulted in the activation of a suppressor $T$ cell, which could influence the immunological response of fresh lymphocytes. We undertook a study to determine if the putative B-cell mitogen contained within the $A$. viscosus supernatant fraction was capable of inducing similar regulatory activity. Lymphocytes were precultured with AV-SUP $(1000 \mu \mathrm{g} / \mathrm{ml})$ for $48 \mathrm{hr}$. As shown in Table 1 , subsequent pokeweed mitogen stimulation (1/100 dilution of stock) of washed precultured cells resulted in a significant amplification of DNA synthetic response compared to control preincubated cultures. Addition of fresh autologous lymphocytes to these precultured cells resulted in a significant amplification of a subsequent mitogen stimulation. This is in contrast to findings in concanavalin A-induced systems, whereby the blastogenic response of the fresh cells are significantly suppressed by precultured cells. It is significant to point out that while in most instances the $\mathrm{E} / \mathrm{C}$ (experimental/control) ratio is greater for cells cultured without additional fresh 
TABLE 1

Effect of $A$. viscosis Preculture on Subsequeni Pokeweed Mitogien Stimul allon on HLMan Peripheral. BloOd Limphocties

\begin{tabular}{|c|c|c|c|c|c|}
\hline \multirow[b]{2}{*}{ Subject } & \multirow[b]{2}{*}{$\begin{array}{l}\text { A. viscosus } \\
\text { pretreatment" }\end{array}$} & \multicolumn{4}{|c|}{$\left[\right.$ Methy/- $\left.{ }^{3} \mathrm{H}\right]$ thymidine incorporation $(\mathrm{cpm} \pm \mathrm{SD})^{*}$} \\
\hline & & $\begin{array}{l}\text { Precultured } \\
\text { cells alone }\end{array}$ & $\mathrm{E} / \mathrm{C}^{\circ}$ & $\begin{array}{l}\text { Precultured cells } \\
\text {-- fresh cells }\end{array}$ & $\mathrm{EC}$ \\
\hline \multirow[t]{2}{*}{1} & - & $5,872 \pm 486$ & & $27.525 \pm 1.801$ & \\
\hline & + & $10.539 \pm 721$ & 1.79 & $45,595 \div 2,011$ & 1.65 \\
\hline \multirow[t]{2}{*}{2} & - & $578+42$ & & $22.898 \pm 1.842$ & \\
\hline & + & $9,388 \pm 511$ & 16.24 & $160,491+4,271$ & 4.88 \\
\hline \multirow[t]{2}{*}{3} & - & $644 \pm 22$ & & $17,333+1,004$ & \\
\hline & - & $4,064 \pm 378$ & 6.12 & $27.370 \pm 1.421$ & 1.58 \\
\hline \multirow[t]{2}{*}{4} & - & $2.255=170$ & & $23.395 \pm 1,380$ & \\
\hline & + & $27,933 \pm 1,008$ & 12.38 & $64,657 \pm 2.202$ & 2.76 \\
\hline 5 & $\begin{array}{l}- \\
+\end{array}$ & $\begin{array}{l}2.748 \pm 214 \\
7.148 \pm 360\end{array}$ & 2.60 & $\begin{array}{l}23.629 \pm 1.075 \\
31.476 \pm 1.521\end{array}$ & 1.33 \\
\hline \multirow[t]{2}{*}{6} & - & $4,931 \pm 481$ & & $29.071+1.040$ & \\
\hline & + & $13.105 \pm 622$ & 2.66 & $39.696 \pm 2.101$ & 1.79 \\
\hline \multirow[t]{2}{*}{7} & - & $960 \pm 101$ & & $6.815 \pm 484$ & \\
\hline & + & $7.497 \pm 682$ & 7.81 & $13.664 \pm 522$ & 2.00 \\
\hline \multirow[t]{2}{*}{8} & - & $161 \pm 27$ & & $9.937 \pm .387$ & \\
\hline & + & $3.326 \pm 294$ & 20.66 & $9.334+502$ & 318 \\
\hline \multirow[t]{2}{*}{9} & $\cdots$ & $1.332 \pm 79$ & & $10.928-488$ & \\
\hline & + & $16,048 \pm 581$ & 12.04 & $67.756-1.741$ & 6.20 \\
\hline \multirow[t]{2}{*}{10} & - & $1.959 \pm 121$ & & $1.957-94$ & \\
\hline & + & $5,606 \pm 437$ & 2.86 & $12,343=428$ & 0.31 \\
\hline
\end{tabular}

"Lymphocytes were precultured in the presence of AV-SUP (1000 $\mu \mathrm{g} / \mathrm{ml})$ or medium alone for 48 hr (Stage 1). After washing, cells were dispensed into microtiter wells 150,000 cells/well), pokeweed mitogen added to each culture (1/100 dilution). and cultured an additional 72 hr iStage 11 . Six hours prior to termination, $\left[m e t h y /{ }^{3} \mathrm{H}\right]$ thymidine was added to each well.

"Expressed as $\triangle \mathrm{cpm}$ (cpm per 100,000 lymphocytes in mitogen-stimulated cultures minus cpm per 100,000 lymphocytes in unstimulated cultures).

"Experimental/control ( $\mathrm{ccpm}$ of AV-SUP-treated cultures/دcpm of untreated cultures/.

autologous cells, the actual magnitude of increased DNA synthetic activity is greater following the addition of fresh cells.

Nature of Cell Responsible for Amplification

The preliminary findings described in Table 1 did not yield information on the nature of this amplification mechanism. It was apparent that this mechanism was unlike the mitogen-induced suppressor models previously described. In order to further characterize this interaction, the influence of mitomycin $\mathrm{C}$ treatment on each cell category added to Stage II cultures upon the amplification phenomenon was examined. Table 2 shows the results of this evaluation, which is characteristic of six such experiments.

Preculture of human lymphocytes for a period of $48 \mathrm{hr}$ appeared to make them refractory to subsequent pokeweed mitogen stimulation when compared to the response of fresh autologous cells. A. viscosus-SUP preculture, in the absence of subsequent mitogen stimulation, resulted in a suppressed response when compared to controls. However, mitogen activation of these cells resulted in a blas- 
TABLE 2

Effect of Mitomycin C Treatment of A. viscosus Preincubated Cells on the Blastogenic Response of Cocultured $A$. viscosus-Preincubated Cells and Fresh Cells"

\begin{tabular}{|c|c|c|c|c|}
\hline & \multicolumn{2}{|c|}{ Unstimulated (cpm) } & \multicolumn{2}{|c|}{ PWM stimulated $(\mathrm{cpm})^{h}$} \\
\hline & Calculated & Observed & Calculated & Observed \\
\hline Fresh cells & - & 120 & - & 9,436 \\
\hline Fresh cells $s_{\text {mito }} c^{\prime \prime}$ & - & 60 & - & 285 \\
\hline Control cells & - & 288 & - & 1.630 \\
\hline AV-precultured cells & - & 39 & - & 20,853 \\
\hline Control cells $_{\text {mitu }}$ c & - & 43 & - & 137 \\
\hline AV-precultured cells $s_{\text {mito } C}$ & - & 72 & - & 292 \\
\hline Fresh cells + control cells & 408 & 50 & 11,066 & 62,001 \\
\hline $\begin{array}{l}\text { Fresh cells }+ \text { AV precultured } \\
\text { cells }\end{array}$ & 159 & 140 & 30.289 & 193,692 \\
\hline $\begin{array}{l}\text { Fresh cells }+ \text { control } \\
\text { cells } \text { mito }^{c}\end{array}$ & 163 & 158 & 9.573 & 11.269 \\
\hline $\begin{array}{l}\text { Fresh cells }+ \text { AV-precultured } \\
\text { cells } s_{\text {mito } c}\end{array}$ & 192 & 344 & 9.728 & 16.687 \\
\hline $\begin{array}{l}\text { Fresh cells } \\
\text { cells }\end{array}$ & 348 & 10 & 1.915 & 10.302 \\
\hline $\begin{array}{l}\text { Fresh cells } \text { mito }+\mathrm{AV}- \\
\text { precultured cells }\end{array}$ & 99 & 83 & 21,138 & 123.812 \\
\hline
\end{tabular}

"The duration of culture was $72 \mathrm{hr}$. Individually cultured cell categories were cultured at $100,000 \mathrm{cells} /$ well to simulate density effects. The observed $\mathrm{cpm}$ in the individually cultured cell categories is reported as one-half of the actual value in order to represent the actual contribution of each cell category to the coculture $(50,000$ cells of each category, 100.000 cells, total). PWM utilized at $1 / 1000$ dilution.

"Expressed as $\Delta$ cpm (counts per minute per 100,000 lymphocytes in PWM-stimulated cultures minus counts per minute in unstimulated cultures). ([Methyl- $\left.{ }^{3} \mathrm{H}\right]$ thymidine).

Mitomycin C-treated, $50 \mu \mathrm{g} / \mathrm{ml}$ for $30 \mathrm{~min}$ at $37^{\circ} \mathrm{C}$.

togenic response of more than 12-fold greater than the control, representing a significant amplification response. These responses could be completely abrogated by mitomycin $\mathrm{C}$ pretreatment.

Pokeweed mitogen stimulation of cocultures of fresh autologous lymphocytes and control precultured cells produced a significant augmentation of blastogenesis over calculated values (approximately fivefold). In addition, the blastogenic response of PWM-stimulated AV-SUP precultured cells was found to be amplified by as much as sixfold over calculated values when fresh autologous cells were added. All calculated values are based on the blastogenic responses of individually cultured cell categories with or without subsequent mitogen stimulation. Calculated values for the cell coculture experiment take into account the amplification arising from the lymphocytes pretreated with AV-SUP and cultured in the absence of fresh cells.

Mitomycin $C$ treatments of the precultured lymphocytes abrogated the amplification effects in coculture studies as previously described in singly cultured experiments. However, mitomycin $C$ treatment of the fresh autologous cells had no effect on the generation of the amplification phenomenon. This indicated that fresh cell-mediated amplification of blastogenesis was not a function of increased 
DNA synthetic activity in the fresh cells, but rather an influence, independent of DNA synthesis, on the precultured lymphocytes.

\section{Effect of AV-SUP Preculture Concentration}

The concentration dependence of the AV-SUP in the Stage I culture required to generate a Stage II amplified response was determined. AV-SUP was tested at concentrations between 10 and $2000 \mu \mathrm{g} / \mathrm{ml}$. As shown in Fig. 1, there is a marked threshold that occurs at $1000 \mu \mathrm{g} / \mathrm{ml}$. Below that concentration, little amplification is evident, even in the presence of fresh autologous lymphocytes (not shown). In addition, concentrations above $1000 \mu \mathrm{g} / \mathrm{ml}$ do not significantly increase the augmented response. This threshold is independent of mitogen used (con A, PWM).

\section{Mitogen Concentration Dependency in Stage II}

As a result of the critical concentration threshold apparent in the Stage I activation of the AV-SUP-induced amplification phenomenon, the concentration of Stage II mitogen activation was assessed. Pokeweed mitogen was assessed between $1 / 10$ and $1 / 1000$ dilutions of standard stock solution, and con A between 0.5 and $50 \mu \mathrm{g} / \mathrm{ml}$ in 10-fold steps. As shown in Fig. 2, at each concentration of PWM, a significant amplification of AV-SUP-mediated response occurred when compared to the control culture. This was also true for con A (not shown).

\section{DISCUSSION}

Members of the family Actinomvetaceate are organisms common to mature dental plaque and are thought to contribute to the development of the cell-

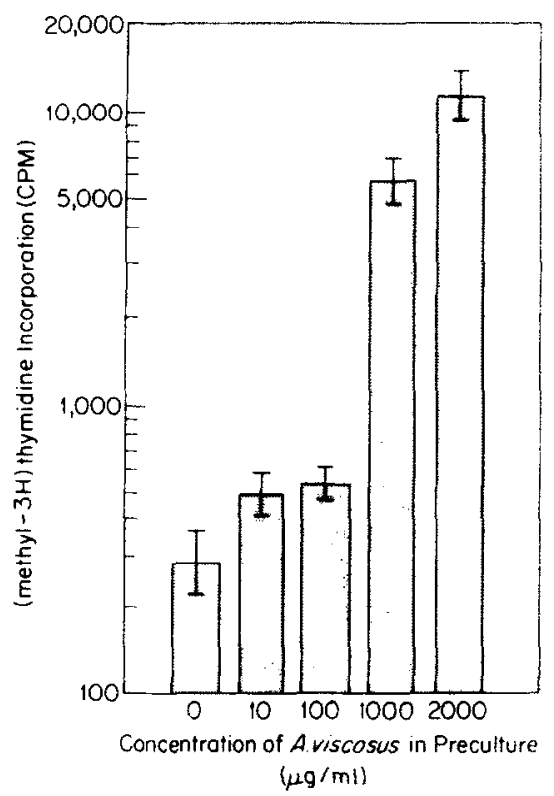

FICi. 1. Dose dependency of AV-SUP in Stage 1 (48-hr preculture) lymphocyte cultures. Stage II cultures were stimulated with constant PWM (1/100) and harvested after $72 \mathrm{hr}$. ( $\triangle \mathrm{cpm}$ is depicted: counts per minute per 100,000 lymphocytes in mitogen-stimulated cultures minus counts per minute per 100,000 lymphocytes in unstimulated cultures.) 


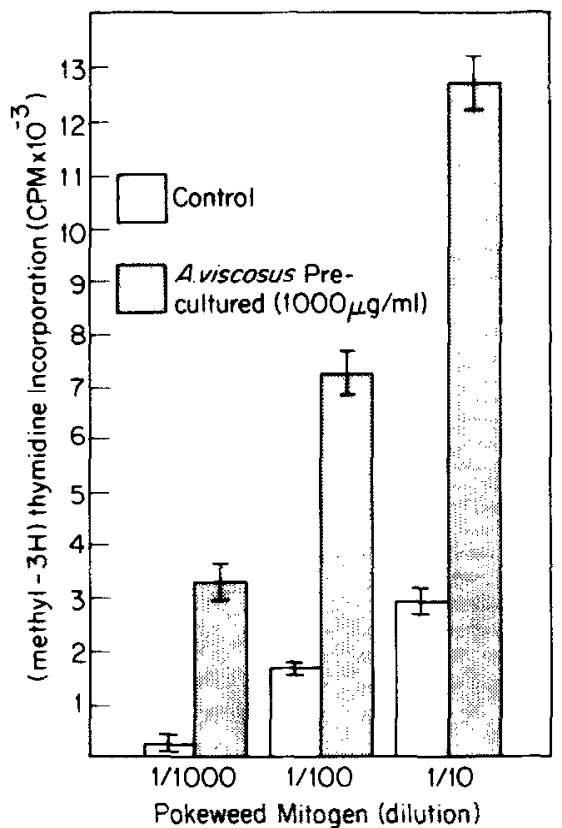

FIG. 2. Dose-response effect of pokeweed mitogen in Stage II culture in the presence of a constant concentration of AV-SUP $(1000 \mu \mathrm{g} / \mathrm{ml})$ in Stage I, 48-hr preincubation. ( $\triangle \mathrm{cpm}$ is depicted: counts per minute per 100,000 lymphocytes in mitogen-stimulated cultures minus counts per minute per 100,000 lymphocytes in unstimulated cultures.)

mediated inflammatory process associated with chronic periodontitis $(19,12)$. Recent reports have illustrated the polyclonal B-cell mitogenic properties of $A$. viscosus extracts and ultrasonicate supernates on murine lymphocytes $(11,10)$. In contrast, studies employing human subjects have indicated that human lymphocyte responses to $A$. viscosus were due to antigen, rather than mitogen, since culture with fetal cord blood or lymphocytes from nonperiodontally diseased subjects did not consistently result in stimulation (13).

Direct activation of blastogenesis is only one possible result of a stimulant-lymphocyte interaction. We attempted to identify an influence of $A$. viscosus supernate (AV-SUP) on lymphocyte-regulatory mechanisms, since the absence of a response may be attributed to an active suppressor mechanism rather than an inability to respond. As previously described by Shou et al. (14), the plant lectin concanavalin $A$ is capable of activating a population of lymphocytes that can suppress lymphocyte responses to antigens and mitogens. Sakane and Green (15) suggested that such an activation may be dissociated from a blastogenic response. Since $A$. viscosus was shown to possess mitogenic properties, it was reasonable to consider the possibility that it might activate a similar regulatory population. Employing a preculture model similar to that of Shou et al. (14), rather than induction of a suppressor cell, AV-SUP preculture and subsequent mitogen stimulation resulted in an amplification of the blastogenic response.

Amplification of lymphocyte blastogenesis may be mediated through a variety of cellular mechanisms (20). Because AV-SUP is a polyclonal B-cell activator in mouse cultures and may induce B-cell maturation, amplification of human B-cell 
differentiation with subsequent immunoglobulin synthesis may also occur and should be compared to the present data on lymphocyte blastogenesis. This comparison is currently in progress in our laboratory.

Enhancement of DNA synthetic activity may represent a functional change in immunoregulation, which could be manifested as either expression of a "helper" activity or as an inactivation of suppressor cell function. Mitomycin $C$ treatment of fresh autologous cells, added to AV-SUP precultured cells, had no effect on the amplification of blastogenesis in response to mitogenic stimulation. In contrast. mitomycin C treatment of AV-SUP-precultured cells abrogated the phenomenon, suggesting that the "regulated" cell is found in the precultured, rather than in the fresh autologous population. This finding indicates a major difference between the AV-SUP and the concanavalin A-activated regulatory cells models $(14,21)$.

Although amplification occurred after preculture in the absence of fresh mononuclear cells, the absolute magnitude of the response was significantly enhanced in the presence of the fresh cells. This finding supports a model based, in part, on the generation of an active "helping" mechanism, rather than a loss of suppressive activity. Additional amplification, upon addition of fresh cells, may represent a lack of sufficient or active helping cells in the AV-SUP-precultured preparations. Dutton (22) reported that lymphocyte preculture resulted in a loss of suppressive activity. Such an explanation may also be applicable to a loss of helper function in our system (which can be supplemented by adding fresh cells).

While data on cells treated with mitomycin $\mathrm{C}$ indicated that the "responding" cells were present in the AV-SUP-precultured population, it is not clear if the amplification is actually a blastogenic response to AV-SUP or to the second stimulant (mitogen). One possible hypothesis currently being evaluated in this laboratory, is that while AV-SUP is recognized by a lymphocyte subpopulation during preculture, a response to AV-SUP may be aborted unless driven to completion by a signal from a mitogen-activatable accessory cell. Such an accessory cell would provide a second signal not generated by AV-SUP alone. In another interpretation. AV-SUP preculture might result in a turn-off of a suppressive anti-activator regulatory cell, permitting a normally unresponsive population of cells to be triggered by either mitogen or AV-SUP. In the presence of a second stimulant, the cells would be driven to final maturation. facilitated by amplifying or "helper" cells in the precultured, or fresh. cell population.

Forbes et al. (23) reported that mouse thymus cells were triggered by LPS only when cultured with minimally mitogenic levels of concanavalin $A$. They suggested that triggering by LPS involved the interaction of a T-cell subpopulation. This subpopulation may contain the amplifying cell in our model, active in Stage II cultures. In studies by duBois et al. (24), irradiated autologous or allogenic cells were shown to be capable of reconstituting in vitro proliferative responses to tetanus toxoid, even if the reconstituting cells were themselves unresponsive to the stimulant. Such findings indicated the existence of a population of regulatory cells capable of complementing cells that are unable to mature to a terminal stage of differentiation on their own. Lack of activation of such a population of "helper" cells would explain the inability or difficulty in observing a human lymphocyte response to putative B-cell polyclonal cell activators in AV-SUP in the absence of a costimulant. 
Accumulation of dental plaque in vivo or its addition to in vitro lymphocyte cultures has been associated with an adjuvant effect. The results of this study are compatible with the hypothesis of Lehner et al. (25) who suggested that an adjuvant effect that was associated with gingivitis or periodontitis might be the result of a focus of commensal organisms which could modulate the cell-mediated response to both related and unrelated antigenic stimulation. The present study supports this basic concept and its extension which suggests that unresponsiveness to a variety of polyclonal B-cell activators in healthy individuals is a result of insufficient helper-cell activity. In the diseased individual, costimulation with unrelated antigens/mitogens results in the generation of nonspecific helper function, allowing response to these "silent" mitogens.

\section{ACKNOWLEDGMENTS}

We thank Dr. Stanley A. Schwartz, Department of Pediatrics. University of Michigan, for his invaluable suggestions on this manuscript; and Ms. Andrea G. Appel for her editorial advice. This study was supported by Public Health Service Grant DE 02731-12 from the National Institute of Dental Research.

\section{REFERENCES}

1. Gronowicz, E., and Coutinho, A., Transplant. Rey. 24, 3, 1975.

2. Damais, C., Bona, C., Chedid, K., Fleck, J., Nauciel, C., and Martin, J. P., J. Immunol. 115, 268, 1975.

3. Peavy, D., Adler, W.. and Smith, R., J. Immunol. 105, 1453, 1970.

4. Schmidtke, J., and Najarian, J., J. Immunol. 114, 742, 1975.

5. Miller, R. A., Gartner, S., and Kaplan, H. S., J. Immunol. 114, 742, 1978.

6. MacDermott, R. P., Nash, G. S., Bertovich. M. J., Merkel, N. S., and Wejnrieb, I. J., C $\bullet / l$. Immunol. 38, 198, 1978.

7. Greaves, M., Janossy, G., and Doenhoff, M., J. Exp. Med. 140, 1, 1974.

8. Lohrman, H. P., Novikous, L., and Graw, R. G., Jr., J. Exp. Med. 139, 1553, 1974.

9. Weksler, M. E., and Kunz, M. M., Immunology 31, 273, 1976.

10. Burckhardt, J. J., Guggenheim, B., and Hefti, A., J. Immunol. 118, 1460, 1977.

11. Engel, D., Clagett, J., Page, R., and Williams, B., J. Imminol. 118, 1466, 1977.

12. Baker, J. J., Chan, S. P., Socransky, S. S.. Oppenheim, J. J., and Mergenhagen, S. E., Infect. Immun. 13, 1363, 1976.

13. Horton, J. E., Oppenheim, J. J., Chan, S. P., and Baker, J. J., Cell. Immunol. 21, $153,1976$.

14. Shou, L., Schwartz, S. A., and Good, R. A., J. Exp. Med. 143, $1100,1976$.

15. Sakane, T., and Green, I., J. Immunol. 119, 1169, 1977

16. Boyum, A., Scand. J. Clin. Lab. Iniest. 21. (Suppl. 97). 1, 1968.

17. Holmberg, K.. and Hallander, H. O..J. Gen. Microbirl. 76, 43, 1973.

18. Loesche, W. J., Hockett, R. N., and Syed, S. A., Arch. Oral Biol. 17, 1311, 1972.

19. Ivanyi, L., and Lehner, T., Arch. Oral Biol. 15, 1089. 1970.

20. Gershon, R. K., In "Contemporary Topics in Immunobiology" (M. D. Cooper and N. C. Warner, Eds.), Vol. 3, pp. 1-40. Plenum, New York, 1974.

21. Hubert. C.. Delepesse, G.. and Gavaerts, A.. Clin. Exp. Immmol. 26, 95, 1976.

22. Dutton, R. C. J. Exp. Med. 136, 1445, 1972.

23. Forbes, J. T., Nakao, Y., and Smith, R. T. J. Immuncl. 114, 1004, 1975.

24. DuBuis, M. J. G. J., Eijlander, A. B., Meinesz. A., and Schellekens, P.T.A., Cell. Immurul, 41, 338,1978

25. Lehner, T., Wilton, J. M. A., Challacombe, S. J., and Ivanyi, L., Clin. Exp. Immanol. 16, 481, 1974. 